\title{
IMPACT OF ACTIVE COMPOUNDS ISOLATED FROM BANANA (MUSA SP. VAR. NANJANGUD RASABALE) FLOWER AND PSEUDOSTEM TOWARDS CYTOPROTECTIVE AND DNA PROTECTION ACTIVITIES
}

\author{
RAMITH RAMU1, PRITHVI S. SHIRAHATTI', SHRISHA NAIK BAJPE2, VARSHA REDDY S. V.1, \\ M. N. NAGENDRA PRASAD ${ }^{3 *}$
}

${ }^{1}$ Department of Biotechnology, Sri Dharmasthala Manjunatheshwara College of Post Graduate Centre, Ujire, Dakshina Kannada 574240, Karnataka, India, 2Department of Studies in Biotechnology, University of Mysore, Manasagangotri, Mysore 570006, Karnataka, India, ${ }^{3}$ Department of Biotechnology, Sri Jayachamarajendra College of Engineering, JSS Institution Camp, Manasagangothri, Mysore 570006, Karnataka, India Email: ramithramu@gmail.com

Received: 06 Jun 2017 Revised and Accepted: 31 Aug 2017

\section{ABSTRACT}

Objective: The present study was designed to evaluate for cytoprotective and DNA protective properties of the compounds isolated from ethanol extract of banana flower (EF) and ethanol extract of banana pseudostem (EE).

Methods: The four active compounds viz., umbelliferone (C1) andlupeol (C2) from EF and stigmasterol (C3) and $\beta$-sitosterol (C4) from EE were isolated by activity-guided repeated fractionation through silica gel column chromatography. The isolated compounds were evaluated for cytoprotective on erythrocytes and pTZ57R/T plasmid DNA protection against hydroxyl radicals.

Results: The study revealed that the compounds (C1-C4) at a concentration of $1 \mathrm{mg} / \mathrm{ml}$ exhibited $90 \%$ protection on erythrocytes membrane oxidation and also protect the pTZ57R/T plasmid DNA damage induced by hydroxyl radicals.

Conclusion: These results endorse an insight for a strong chemical basis to the alleged bene ficial role of EF and EE in reducing oxidative stress conditions Keywords: Umbelliferone, Lupeol, Stigmasterol, $\beta$-Sitosterol

(C) 2017 The Authors. Published by Innovare Academic Sciences Pvt Ltd. This is an open access article under the CC BY license (http://creativecommons.org/licenses/by/4.0/) DOI: http://dx.doi.org/10.22159/ijpps.2017v9i10.20560

\section{INTRODUCTION}

India ranks a considerable position for the largest production of banana fruit in the world followed by Brazil and China [1]. Banana (Musa spp.), as a major fruit of India accounts for about $32 \%$ of the total fruit production and is considered to be a good source of biologically active compounds such as dopamine, $\mathrm{N}$-acetyl serotonin, nor-adrenaline, isochronal-4-one derivatives and polyphenols with high antioxidant properties [2-6]. The Indian traditional forms of medicines like Ayurveda and Folkloric have been exploiting roots, stalks, leaves, fruits and different parts of the banana plant for the treatment and reclaim in the diseases like gout, kidney stones, ulcers, inflammation, fevers, burns, skin diseases, diarrhoea and snakebite [7]. Despite the literature available for its utilitarian value and diverse pharmacological activities viz., antiulcerogenic [8,9], hypolipidemic [10], antimicrobial, antihypertensive [11], wound healing, antacid, diuretic and antiestrogenic activities [12], a systematic activity guided isolation, identification and characterization of antioxidants from the distinct parts of banana have not been performed to date. Isolation and identification of new antioxidants such as phenolic compounds, nitrogen compounds, carotenoids and other phytochemicals from natural sources are gaining special interest in the prevention of diseases and as well for its ample health benefits over synthetic antioxidant compounds [13]. More recently, banana flower and pseudostem being incidental or secondary products of banana were found to contain a large amount of dietary fibres conjunct with polyphenols [14]. In this context, an efficient activity-guided isolation and identification for bioactive compounds were performed in the ethanol extract of banana (Musa sp. var. Nanjangud rasa bale) flower (EF) and pseudostem (EE). Nanjangud rasa bale (Nrb) is an elitist innate variety of banana originated from a divine place known as 'Nanjangud' in Karnataka, India. Unique characteristics of Nrb such as taste, fibrous texture, nutritional content and its distinct aroma when it ripens fully makes it very popular and exotic variety of banana in Karnataka. Herein the isolation and identification of four potent active compounds, Umbelliferone (C1) and Lupeol (C2) from the ethanol extract of banana flower (EF) and Stigmasterol (C3) and $\beta$-Sitosterol (C4) from ethanol extract of banana pseudostem (EE) were illustrated by spectroscopic means $[15,16]$. Therefore, the objective of this study was to investigate the protective effect of the isolated compounds by free radical-induced damage on erythrocytes and DNA.

\section{MATERIALS AND METHODS}

Chemicals

Reagents and solvents used for extraction were procured from Merck (Mumbai, India). The standard drugs were purchased from Sigma-Aldrich Chemical Co (St. Louis, MO, USA). All other reagents were of analytical grade.

\section{Plant material}

Fresh banana pseudostem and inflorescence of Musa sp. cv. Nanjangud rasa bale were collected from banana cultivating farms of Nanjangud, Karnataka, India at coordinates $12.11^{\circ} 7^{\prime} 11^{\prime \prime}$ North, $76.70^{\circ} 40^{\prime} 58^{\prime \prime}$ East. The specimen (Reg. No.: A4) was identified by the department of Horticulture, Government of Karnataka, Mysore, India. Peeling the thick outer leaf-sheath of the tender pseudostem, the inner pith region was collected. Flowers were separated from the inflorescence followed by discarding the spathe. Both pseudostem and flowers were cleaned, cut into small pieces and dried at $40{ }^{\circ} \mathrm{C}$ in an oven. This was powdered using a homogenizer and further stored at $4{ }^{\circ} \mathrm{C}$ until use.

\section{Preparation of extract and isolation of active compounds}

The coarse powder was subjected to hot ethanol extraction using a Soxhlet apparatus (twice using 95\% ethanol) and filtered. The filtrate was further concentrated in vacuo using rotary evaporator (Rotavapor R-200, Buchi, Switzerland). The active compounds present in EF were identified as Umbelliferone and Lupeol, while 
Stigmasterol and $\beta$-Sitosterol from EE using various spectroscopic methods via successive solvent extraction followed by repeated silica gel column chromatography $[15,16]$.

\section{DNA protection assay}

The extent of protection against pTZ57R/T plasmid-DNA damage by isolated bio active compounds was evaluated as described by Lee et al., [17]. $2 \mu \mathrm{l}$ of plasmid DNA was incubated with Fenton's reagent (30 mmol H202, $50 \mu \mathrm{M}$ ascorbic acid and $80 \mu \mathrm{M} \mathrm{FeCl3}$ ) containing $0.2 \mathrm{mg} / 3 \mu \mathrm{l}$ of compounds and final volume of the mixture was raised up to $15 \mu \mathrm{l}$ with sterile water. The latter was then incubated for $30 \mathrm{~min}$ at $37^{\circ} \mathrm{C}$ followed by the addition of loading dye. The DNA was analyzed on $1 \%$ agarose gel by carrying out the electrophoresis in TAE buffer ( $40 \mathrm{mmol}$ Tris base, $16 \mathrm{mmol}$ acetic acid, $1 \mathrm{mmol}$ EDTA, pH 8.0) and further stained with ethidium bromide using gallic acid as positive control.

\section{Cytoprotective studies of active compounds on erythrocytes}

The cytoprotective studies of erythrocyte oxidation were done according to Suwalsky et al., [18]. Briefly, blood sample was collected from healthy donors in heparinized tubes. The tubes were gently mixed and centrifuged at $1000 \mathrm{~g}$ for $15 \mathrm{~min}$ to sediment the erythrocytes. The supernatant containing plasma was discarded. The pellet containing erythrocytes was washed 2-3 times with PBS $(20$ mmol, $\mathrm{pH} 7.4, \mathrm{NaCl}-$ $0.9 \%$ ) and re-suspended with four times the volume of PBS. The compounds were added at $1 \mathrm{mg} / \mathrm{ml}$ volume, pre-incubated at room temperature for $5 \mathrm{~min}$ followed by addition of hydrogen peroxide (30 mmol), ferric chloride $(80 \mu \mathrm{M})$ as well as ascorbic acid (50 $\mu \mathrm{M})$ and incubated at $37^{\circ} \mathrm{C}$ for $1 \mathrm{~h}$. During the course of incubation, the reaction mixture was gently shaken to ensure constant proper mixing. The morphological changes were observed and captured (Olympus12.8 megapixel digital camera, DP72) using Olympus microscope (BX41, DSS Imagetech Pvt. Ltd., New Delhi, India).

\section{RESULTS AND DISCUSSION}

\section{DNA protection assay}

DNA protective ability of the compounds (C1)-(C4) wereevaluated to test their efficacy in protecting the DNA against oxidative damage (fig. 1). The oxidative damage induced by Fenton's reagent generates hydroxyl free radical leading to DNA fragmentation with increase in its electrophoretic mobility [19] as evident in lane 2. This DNA fragmentation was recovered upon treatment with the compounds and gallic acid (lane 3-7).

\begin{tabular}{|c|c|c|c|c|c|c|c|}
\hline & 1 & 2 & 3 & 4 & 5 & 6 & 7 \\
\hline & $=$ & - & $=$ & $=$ & 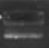 & $=$ & $=$ \\
\hline & - & & - & - & - & $\div$ & - \\
\hline Native DNA & + & + & + & + & + & + & - \\
\hline Compound 1 & - & - & + & - & - & - & - \\
\hline Compound 2 & - & - & - & + & - & - & - \\
\hline Conpound 3 & - & - & - & - & + & - & - \\
\hline Compound 4 & - & - & - & - & - & + & - \\
\hline Gallic acid & - & - & - & - & - & - & - \\
\hline Fenton's reagent & - & + & + & + & + & + & + \\
\hline
\end{tabular}

Fig. 1: Electrophoretic analysis of DNA protection by isolated compounds (C1)-(C4) in addition with standard gallic acid $(0.2$ $\mathrm{mg} / 3 \mu \mathrm{l}$ concentration). Lane 1-Native DNA, Lane 2-DNA+0xidant,

Lane 3-DNA+Compound 1 (umbelliferone)+Oxidant, Lane 4DNA+Compound 2 (lupeol)+Oxidant, Lane 5-DNA+Compound 3 (stigmasterol)+0xidant, Lane 6-DNA+Compound 4 ( $\beta$ sitosterol)+0xidant, Lane 7-DNA+Gallic acid+0xidant

In agreement to the gel documentation analysis, higher protection $(80 \%)$ was observed in gallic acid treated sample, whereas $75 \%$, $67 \%, 56 \%$ and $59 \%$ protection was observed for compounds (C1)(C4) treated samples respectively.

\section{Cytoprotective studies of erythrocyte oxidation}

Erythrocytes are extensively used model cells for studies on oxidative stress induced cell damage. Oxidative stress induces an echinocytic type of cell alteration and characterized protuberance over the cell membrane [20]. Therefore the protective ability of the isolated compounds on erythrocyte oxidation was studied as there were no reports found on cytoprotective abilities of these compounds.
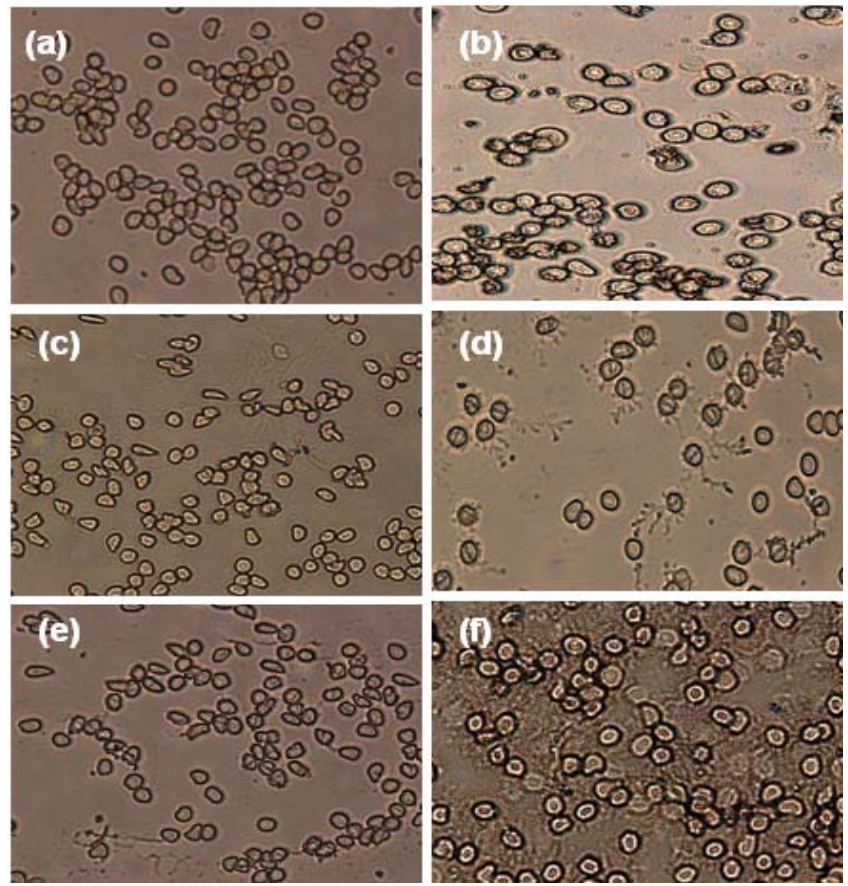

Fig. 2: Microscopic evaluation of erythrocyte morphology represented as (a) Control-red blood cells (RBC's); (b) RBC's+oxidant; (c-f) RBC's+compound (1)-(4) at $1 \mathrm{mg} / \mathrm{ml}$ [compound 1: umbellifeone (c), compound 2: lupeol (d), compound 3: stigmasterol (e), compound 4: $\beta$-sitosterol (f)]+oxidant after $1 \mathrm{~h}$ of incubation 
The optical micrographs (fig. 2a-f) shows the presence of normal cells in addition to oxidised cells indicating the cytoprotective role of compounds (C1)-(C4) treated samples. As compared to normal erythrocytes (fig. 2a) subjected to hydrogen peroxide and ascorbate $/ \mathrm{Fe}^{2+}$ led to the oxidation of cell membrane rendering distorted and clustered appearance (abnormal erythrocyte-fig. 2b). From our results, it is evident that the isolated compounds were efficient in bringing down the oxidative stress-induced erythrocyte damage and could also revert back the echinocytic shape alteration as well the characteristic protuberances of the cell membrane as observed in fig. $2 \mathrm{c}-\mathrm{f}$.

Plants being a rich source of a myriad of bioactive ingredients and phytoconstituents, are the most attractive options to circumvent the problems faced by the administration of synthetic drugs. References of traditional form of medicine have provided a basis for research on such natural products in the treatment of several diseases [21]. Secondary metabolites isolated from banana flower and pseudostem contained predominantly phenolic group of compounds and phytosterols respectively would be responsible for its cytoprotective and DNA protective activities. Recently, such compounds have attracted a wide consideration for its potential protective role against oxidative damage diseases. The isolation and characterization of bioactive compounds, Umbelliferone and Lupeol from EF and Stigmasterol and $\beta$-Sitosterol from EE supports this statement. The activities ascended in the order: Umbelliferone $>$ Stigmasterol $>$ Lupeol $>\beta$-Sitosterol. These findings establish the isolated compounds as prospective drug attributes.

\section{CONCLUSION}

In conclusion, this study endows the additional data to the literature about potential bioactive compounds from EF and EE. Also it suggests that this traditional form of medicine could be supplemented as a diet or in the form of nutraceutical for the treatment of oxidative damage diseases.

\section{ACKNOWLEDGEMENT}

Ramith Ramu thanks TEQIP, New Delhi, India for awarding the Research fellowship. The authors also thank The Principal, SJCE, Mysore, for his encouragement.

\section{AUTHORS CONTRIBUTION}

\section{N NAGENDRA PRASAD: Designed the work}

RAMITH RAMU: Data collection and analysis

PRITHVI S SHIRAHATTI: Wrote the manuscript

SHRISHA NAIK BAJPE and VARSHA REDDY S V: Contributed the materials/analysis tools/reagents

\section{CONFLICT OF INTERESTS}

There is no conflict of interest to declare

\section{REFERENCES}

1. Joshi S. Eugenia jambolana, Musa paradisiacal L. In: Joshi S. Medicinal Plants. Oxford and IBH Publishing Co. Pvt. Ltd: New Delhi; 2000. p. 286-94.

2. Someya S, Yoshiki Y, Okubo K. Antioxidant compounds from bananas (Musa cavendish). Food Chem 2002;79:351-4.

3. Kanazawa K, Sakakibara H. High content of dopamine, a strong antioxidant in Cavendish banana. J Agric Food Chem 2000;48:844-8.

4. Pari L, Umamaheshwari J. Antihyperglycemic activity of Musa sapientum flowers-effect on lipid peroxidation in alloxan diabetic rats. Phytother Res 2000;14:136-8.
5. Hai Q, Wen LH, Xiao MW, Hui BZ, Jin PZ, Wen CY. A new isochroman-4-one derivative from the peel of Musasapientum (L) and its total synthesis. Chinese Chem Lett 2007;18:1227-30.

6. Waalkes TP, Sjoerdsma A, Creveling CR, Weissbach H, Udenfriend S. Serotonin, norepinephrine and related compounds in bananas. Science 1958;127:648-53.

7. Pellai N, Aashan TN. Ayurveda Prakashika. (Reddiar and Son). Vidyarambha Press: Quilon, India; 1955. p. 97-115.

8. Goel RK, Sairam K. Anti-ulcer drugs from indigenous sources with emphasis on Musa sapientum, Tamrabhasma, Asparagus racemosus and Zingiber officinale. Indian J Pharmacol 2002;34:100-10.

9. Lewis DA, Fields WN, Shaw GP. A natural flavonoid present in unripe plantain banana pulp (Musasapientum L. var paradisiaca) protects the gastric mucosa from aspirin-induced erosions. J Ethnopharmacol 1999;65:283-8.

10. Gomathy R, Vijayalakshmi NR, Kurup PA. Hypolipidemic principle of the inflorescence stalk of plantain (Musa sapientum). J Bioscien 1989;14:301-9.

11. Anonymous. The Wealth of India. Council of Scientific and Industrial Research: New Delhi, India; 2003. p. 178-85.

12. Jain DL, Baheti AM, Ingale SP, Ingale PL, Parakh SR. Study of antacid and diuretic activity of ash and extracts of Musa sapientum (L) fruit peel. Pharmacogn Magaz 2007;3:116-9.

13. Devasagayam TPA, Tilak JC, Boloor KK, Ketaki SS, Saroj SG, Lele RD. Free radicals and antioxidants in human health: Current status and future prospects. J Assoc Phys India 2004;52:794-804.

14. Jamuna JB, Mahadevamma S, Nandini D, Salimath PV. Banana (Musa sp. var. elakki bale) flower and pseudostem: dietary fiber and associated antioxidant capacity. J Agric Food Chem 2012;60:427-32.

15. Ramith R, Prithvi SS, Farhan Z, Lakshmi VR, Nagendra MNP. Inhibitory effect of banana (Musa sp. var. Nanjangud rasa bale) flower extract and its constituents Umbelliferone and Lupeol on $\alpha$-glucosidase, aldose reductase and glycation at multiple stages. South Afr J Bot 2014;95:54-63.

16. Ramith R, Prithvi SS, Nanjunda SS, Zameer F, Bhadrapura LD, Nagendra PMN. Assessment of in vivo antidiabetic properties of umbelliferone and lupeol constituents of banana (Musa sp. var. Nanjangud Rasa Bale) flower in hyperglycaemic rodent model. PLoS One 2016;11:e0151135. Doi:10.1371/journal.pone.0151135.

17. Lee JC, Kim J, Jang YS. Antioxidant property of an ethanol extract of the stem of opuntia ficus-indica var. saboten. J Agric Food Chem 2002;5:6490-6.

18. Suwalsky M, Orellana P, Avello M, Villena F. Protective effect of Ugni molinae Turcz against oxidative damage of human erythrocytes. Food Chem Toxicol 2007;45:130-5.

19. Harish NMA, Sathisha UV, Shylaja MD. Cytoprotective and antioxidant activity of free, conjugated and insoluble-bound phenolic acids from swallow root (Decalepis hamiltonii). Food Chem 2010;119:1307-12.

20. Harish NMA, Sathisha UV, Manohar MP, Chandrashekar KB, Shylaja MD. Cytoprotective and antioxidant activity studies of jaggery sugar. Food Chem 2009;115:113-8.

21. Hazrulrizawati AH, Senait SZ, Mashitah MY Rhodomyrtustomentosa: a phytochemical and pharmacological review. Asian J Pharm Clin Res 2017;10:10-6.

\section{How to cite this article}

- Ramith Ramu, Prithvi S Shirahatti, Shrisha Naik Bajpe, Varsha Reddy SV, MN Nagendra Prasad. Impact of active compounds isolated from banana (MUSA SP. VAR. nanjangud rasabale) flower and pseudostem towards cytoprotective and DNA protection activities. Int J Pharm Pharm Sci 2017;9(10):21-23. 